\title{
Integrated Territorial Investments - Current and Future Solutions for Sustainable Development
}

\author{
Laura-Delia ANGHELUTA ${ }^{\star}$, Silvius STANCIU ${ }^{\star} \star$
}

\begin{tabular}{l}
\hline \multicolumn{1}{c}{ A R T I C L E I N F O } \\
\hline Article history: \\
Accepted August 2020 \\
Available online August 2020 \\
\hline JEL Classification \\
F30, F63, 018, R58 \\
Keywords: \\
Integrated territorial investments, \\
Local development, European \\
funds
\end{tabular}

\begin{abstract}
A B S T R A C T
The aim of the article is the analysis of one of the newest instruments of the Cohesion Policy for the 2014-2020 period, namely the integrated territorial investments (ITI). The advantages offered by ITI to stimulate the integrated approach of the different spheres: the functional territorial one, the implementation of a "bottom-up" strategy with the delegation of tasks at local level and, last but not least, the combination of European and investment funds from several priority axes of operational programmes, converge towards a further use of this instrument in the future programming period 2021-2027. The research was based on different models of ITI in the European Union, an analysis of the operation and results being made for ITI Danube Delta.
\end{abstract}

(C) 2020 EAI. All rights reserved.

\section{Introduction}

The issue of the use of European funds and their impact on the economic growth in the Member States of the European Union (EU) is a constant concern of the various European or national institutions. Thus, the effectiveness of interventions is linked, on the one hand, to the support at national level, but also to the sectoral approach and support for underdeveloped regions as part of EU Cohesion Policy.

The confrontations the EU must face (Brexit, refugee issues, increase of the competitiveness of developed Member States for value-added areas, diversity of needs, etc.) have led to the need for an integrated approach leading to the EU's strategic development (Stanciu, 2016). The territorial cohesion objective introduced by the Lisbon Treaty (adopted in 2009), the Europe 2020 Strategy, the Territorial Agenda of the European Union 2020 promotes the policy of area-based development, in order to streamline activities and synergy types of interventions.

The European Commission's assessments anticipated development disparities at EU level by proposing for the 2014-2020 period two innovative instruments for the Cohesion Policy: Community-Led Local Development (CLLD) and Integrated Territorial Investment. These were regulated by Regulation (EU) No. 1303/2013 laying down common provisions, but also through regulations specific to the European Structural and Investment Funds (ESIF).

The paper treats Integrated Territorial Investments as a tool for implementing territorial strategies based on a well-established territory (urban, urban-rural, etc.) with an integrated territorial development strategy; a series of well-defined actions that are found in the operational programmes funded from ESI Funds but also governance mechanisms in order to manage ITI.

Through the Partnership Agreement signed by Romania with the European Commission, only one ITI was designated at national level, respectively the specific territory of the Danube Delta Biosphere Reserve ITI Danube Delta. The research followed the management of the ITI Danube Delta, but also the absorption capacity of European funds.

\section{Literature review}

The current 2014-2020 programming period has introduced a new tool to implement the Cohesion Policy at EU Member State level. Thus, the approach of integrated territorial investments is found in the three regulations of the European Parliament and the EU Council of December 2013, respectively in art. 36 of the Regulation No. 1303/2013 laying down common provisions, art. 7 of the Regulation no. 1301/2013 on the European Regional Development Fund and art. 12 of the Regulation no. 1304/2013 on the European Social Fund. 
According to the Partnership Agreement for Romania - 2014-2020, Romania uses the ITI instrument in the Danube Delta Biosphere Reserve, this being defined as a unique territory with specific characteristics: "scarce and isolated population, specialization and economic vulnerability, unsatisfactory access to services, etc." (Partnership Agreement, 3.1.2. Integrated Territorial Investment, p. 255).

European Union policies with direct applicability on territorial development and partnership modalities have also been the basis for this research.

Being a new tool introduced by the EU, the literature on ITI is quite limited, but there are a number of specific studies and analyses carried out by Member States that use this tool, but also a number of reports by European institutions in order to analyse the efficiency of ITI in the 2014-2020 period and its use also for the 2021-2027 period.

\section{Methods}

The paper is based on a series of reports, studies and research, the information being obtained mainly from the official EU websites ((https://europa.eu, http://www.europarl.europa.eu) or other specialized sites (https://www.researchgate.net).

Data on the ITI situation in the EU was taken from https://cohesiondata.ec.europa.eu, and information on the ITI Danube Delta from its official website http://www.itideltadunarii.com. At the same time, information was processed from the websites with attributions in the field - Ministry of European Funds (mfe.gov.ro or http://www.fonduri-ue.ro), the Ministry of Public Works, Development and Administration (https: / /www.mlpda.ro), the Ministry for Transport (http://www.mt.gov.ro) and the Ministry of Agriculture and Rural Development (http://www.madr.ro).

Furthermore, the analysis was based on EU regulations on European funds (https://eurlex.europa.eu).

The analysis followed the approach of some Member States on the new ITI instrument and, also, the existing results so far in Romania on the implementation and operation of ITI.

\section{Results}

Starting from a series of studies on EU policies and analysing the objectives of the Europe 2020 Strategy for smart and sustainable growth and favourable for inclusiveness, it is found that the objectives of EU Cohesion Policy for 2014-2020 aim to strengthen the performance by focusing on results and maximizing the impact of funds through thematic focus, having a strategic and integrated approach (Stanciu, 2017).

The new territorial development instruments proposed by the EU for the 2014-2020 period - ITI and CLLD - are innovative and quite complex, they can coexist in the same space (CLLD can be part of an ITI), differing by participatory size and geographical application (CLLD applies locally, while ITI addresses wider territories) and combining funding flows.

The two instruments play an important role in adapting to demographic change and reducing interregional development imbalances. Thus, although ITI was originally intended to be limited to urban areas, it has applicability in urban neighbourhoods, metropolitan areas, urban-rural, sub regional or crossborder.

The defining elements of an ITI focus on a well-defined territory based on an integrated territorial development strategy, a set of actions to be implemented and its own governance mechanism for ITI management.

The advantages offered by ITI concern the possibility of allocating and using European structural and investment funds from several priority axes of the operational programmes for the implementation of the actions of the integrated territorial strategies. Thus, in addition to Cohesion Policy funds, the European Agricultural Fund for Rural Development (EAFRD) and the European Maritime and Fisheries Fund (EMFF) can also be used.

ITI combines the investment priorities set out in the operational programmes with the needs identified by local communities, ensuring, in practice, a synergy between European funds and local needs. The combination of infrastructure investments funded by the European Regional Development Fund with investments in human capital using the European Social Fund is relevant for the sustainable development of an ITI intervention area, just as the EAFRD and the EMFF can be combined to support the urban-rural development of the areas of an ITI.

The territorial approach of interregional policy through the application of intervention packages to certain types of territories and the diversification of actions based on the characteristics of some areas has become one of the concerns of regional policy, the selection of areas being a challenge for Member States. Under the partnership agreements with the EU, ITI tools are being implemented at the level of 20 Member States with various implementation mechanisms based on different geographical, thematic, financial and organizational approaches. Thus, ITI supports functional urban areas in Poland, the Czech Republic, Slovakia, while in the United Kingdom, Germany and Belgium it applies only in certain regions. Finland implements "6 Cities Strategy" supporting ITI in Helsinki, Vantaa, Espoo, Tampere, Oulu and Turku. 
The financial dimension of ITI allocations consists of 13.6 billion Euros, the highest percentage being from the European Regional Development Fund (85.51\%), while 12.32\% is the European Social Fund and $2.17 \%$ the Cohesion Fund (Ionescu et al, 2019).

At the same time, it should be noted that at EU level there are 209 sustainable integrated urban development strategies used as ITIs and 120 ITIs implementing their own strategy. According to the requirements of the European Commission, Member States had to allocate at least 5\% of the Cohesion Policy budget for the implementation of the ITI, each setting its own rules for the selection of areas supported for integrated actions and the indicative allocation in the Partnership Agreements.

Poland stands out due to the largest amount allocated to territorial instruments (over EUR 6 billion) allocated for 24 strategies, most of which are located around regional capitals, 6 being metropolitan areas. Spain has 128 territorial and urban strategies, while Romania has focused on a single homogeneous territory - the Danube Delta Biosphere Reserve which includes the territories of Tulcea and Constanta counties.

The integrated strategy for the sustainable development of the Danube Delta has been implemented with the support of the World Bank, and the action plan includes interventions and implementation mechanisms that allow the use of all European structural and investment funds. The strategy is based on five pillars meant to ensure the development of the territory, these being:

$\checkmark$ protection of the environment and natural resources;

$\checkmark$ improving the economy;

$\checkmark$ improving connectivity;

$\checkmark$ providing public services;

$\checkmark$ promoting efficiency, accessibility and sustainability (http://www.itideltadunarii.com).

The choice of the Danube Delta Biosphere Reserve was based on the specific characteristics of the territory, namely the low population density and isolation, low access to services, poor economic development.

The territory targeted by ITI Danube Delta includes the city of Tulcea, the cities of Babadag, Isaccea, Macin and Sulina, 29 communes from Tulcea county and 4 communes from Constanta county.

To ensure the governance mechanisms of ITI in order to organize, fund, monitor and jointly coordinate the implementation of the Integrated Strategy and the allocated funds, the Association for Intercommunity Development - ITI Danube Delta (AID-ITI DD) was created. AID ITI DD is a legal entity under private law, with public utility status, which has as associates the representatives of 38 administrativeterritorial units, respectively the county councils of Constanta and Tulcea, 5 urban and 33 rural administrative territorial units.

The Quadripartite Protocol concluded between the Ministry of European Funds, the Ministry of Regional Development and Public Administration, the Ministry of Agriculture and Rural Development and the Association for Intercommunity Development - ITI Danube Delta, establishes the role of AID ITI DD to coordinate the implementation of the strategy in the territory, supporting the Managing Authorities in order to implement the ITI mechanism, monitoring the implementation of projects and ensuring the visibility and permanent public information specific to the implementation of the actions of the Integrated Sustainable Development Strategy.

The total estimated budget allocated for the ITI Danube Delta is approximately EUR 1.11 billion from the European structural and investment funds to which is added the national co-funding, the situation being summarized in the following table.

Table 1. 2014-2020 financial allocation for ITI Danube Delta

\begin{tabular}{|l|c|l|}
\hline \multicolumn{1}{|c|}{ Programme } & $\begin{array}{c}\text { Financial allocation } \\
\text { (mil. euros) }\end{array}$ & \multicolumn{1}{c|}{ ESI Fund } \\
\hline $\begin{array}{l}\text { Large Infrastructure Operational Programme } \\
\text { (LIOP) }\end{array}$ & 407.64 & $\begin{array}{l}\text { Cohesion Fund, } \\
\text { European Regional Development } \\
\text { Fund }\end{array}$ \\
\hline Regional Operational Programme (ROP) & 358.1 & $\begin{array}{l}\text { European Regional Development } \\
\text { Fund }\end{array}$ \\
\hline Competitiveness Operational Programme (COP) & 60 & $\begin{array}{l}\text { European Regional Development } \\
\text { Fund }\end{array}$ \\
\hline Human Capital Operational Programme (HCOP) & 60 & European Social Fund \\
\hline $\begin{array}{l}\text { Operational Programme Administrative } \\
\text { Capacity (OPAC) }\end{array}$ & 16 & European Social Fund \\
\hline $\begin{array}{l}\text { Technical Assistance Operational Programme } \\
\text { TAOP) }\end{array}$ & 5 & $\begin{array}{l}\text { European Regional Development } \\
\text { Fund }\end{array}$ \\
\hline $\begin{array}{l}\text { National Rural Development Programme } \\
\text { (NRDP) }\end{array}$ & $\begin{array}{l}168, \text { including the } \\
\text { national contribution }\end{array}$ & $\begin{array}{l}\text { European Agricultural Fund for Rural } \\
\text { Development }\end{array}$ \\
\hline European Maritime and Fisheries Fund (EMFF) & 37 & $\begin{array}{l}\text { European Maritime and Fisheries } \\
\text { Fund }\end{array}$ \\
\hline
\end{tabular}

Source: Authors, by using http://www.itideltadunarii.com 
The area of intervention of the funding programmes targets both local public authorities and institutions, as well as the economic environment or civil society, including the partnerships established between them. Regarding the attraction of the allocated funds, the situation can be seen in table no. 2

Table 2. Situation of use of ITI Danube Delta funds on 30 April 2020

\begin{tabular}{|c|c|c|c|c|c|c|c|}
\hline Programme & $\begin{array}{l}\text { Allocation (ESIF+ } \\
\text { state budget) LEI }\end{array}$ & $\begin{array}{l}\text { ITI allocation } \\
\text { EUR }\end{array}$ & $\begin{array}{l}\text { Number } \\
\text { of } \\
\text { contracted } \\
\text { projects }\end{array}$ & $\begin{array}{c}\text { Value of } \\
\text { contracted } \\
\text { projects } \\
\text { (ESIF+SB) LEI }\end{array}$ & $\begin{array}{c}\% \\
\text { contracte } \\
\text { d projects }\end{array}$ & $\begin{array}{l}\text { Amounts } \\
\text { reimbursed } \\
\text { LEI }\end{array}$ & $\begin{array}{c}\text { Absorpti } \\
\text { on rate } \\
\%\end{array}$ \\
\hline $\begin{array}{l}\text { Regional Operation } \\
\text { Programme }\end{array}$ & 2.136 .190 .680 & 446.034 .006 & 293 & 1.270 .399 .655 & 59.47 & 296.347 .225 & 23.33 \\
\hline Large Infrastructure OP & 2.141 .484 .283 & 447.997 .058 & 29 & 2.337 .847 .872 & 109.17 & 443.406 .934 & 18.97 \\
\hline $\begin{array}{l}\text { OP for Fisheries and } \\
\text { Maritime Affairs }\end{array}$ & 157.882 .000 & 41.099 .527 & 53 & 114.209 .814 & 72.34 & 20.806 .448 & 18.22 \\
\hline $\begin{array}{l}\text { Administrative } \\
\text { Capacity OP }\end{array}$ & 35.350 .000 & 16.000 .000 & 4 & 4.310 .752 & 12.19 & 551.900 & 12.80 \\
\hline Competitiveness OP & 56.873 .268 & $60,000,000$ & 4 & 7.564 .335 & 13.30 & 2.632 .986 & 34.81 \\
\hline Human Capital OP & 165.668 .150 & 60.000 .000 & 7 & 62.892 .714 & 37.96 & 7.804 .572 & 12.41 \\
\hline $\begin{array}{l}\text { Technical Assistance } \\
\text { OP }\end{array}$ & 23.500 .000 & 5.000 .000 & 2 & 28.015 .022 & 119.21 & 11.230 .206 & 40.09 \\
\hline $\begin{array}{l}\text { National Rural } \\
\text { Development } \\
\text { Programme } \\
\end{array}$ & 809.599 .120 & 168.000 .000 & 653 & 659.516 .651 & 81.46 & 291.628 .720 & 44.22 \\
\hline
\end{tabular}

Source: Authors, by processing data from http://www.itideltadunarii.com;

EUR BNR exchange rate from $30.04 .2020=4,8421$ lei

There is a low rate of absorption of ESI funds mainly due to cumbersome procedures for launching funding, poor preparation of beneficiaries, but also the lack of resources and cultures in the development and implementation of European projects (figure 1)

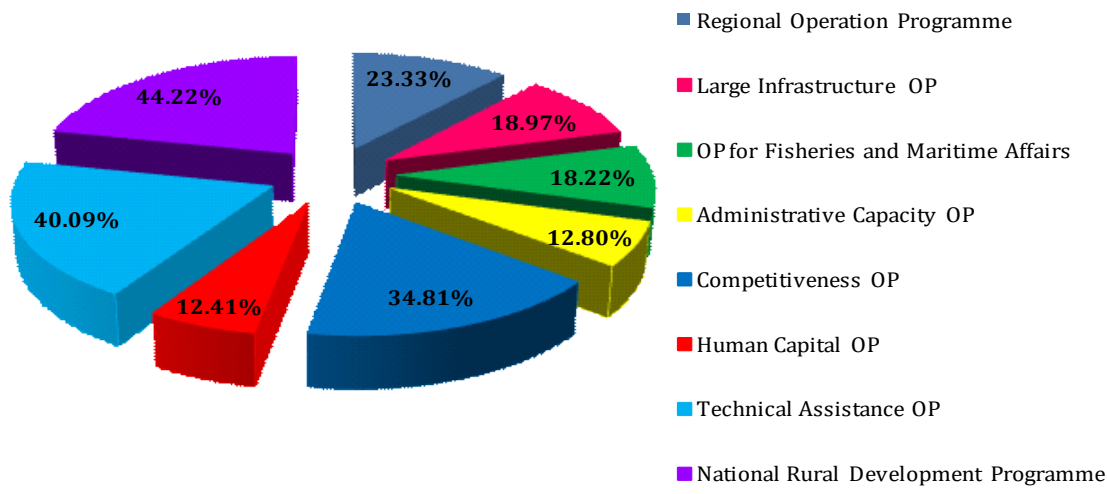

Figure 1. Absorption rate of ESI funds as at 30 April 2020 Source: Authors, by using ADI ITI Delta Dunării (2020),

It is also observed that the largest allocations are from the Regional Operational Programme and the Large Infrastructure Operational Programme, which involves the involvement of local public authorities in the preparation and implementation of projects involving infrastructure investments. Bureaucracy of public authorities, application and compliance with public procurement procedures to ensure the technical documentation needed to carry out investment projects often lead to delays in applying for funding.

At the same time, in addition to the overall analysis of the operational programmes, the number of axes specific to each programme that is applicable in the ITI territory must be taken into account. Thus, in the case of ROP there are 7 specific axes where funding can be requested, which leads to delays in launching, evaluating and subsequently implementing projects.

According to the available information of AID ITI Danube Delta, the contracts concluded locally within NRDP and ROP can be divided into three categories, depending on their size:

$\checkmark$ between 100.000 - 999.9999 Eur: 5 administrative territorial units;

$\checkmark \quad$ between 1.000.000 - 9.999.999 Eur: 27 administrative territorial units;

$\checkmark$ between 10.000.000 - 99.999.999 Eur: 5 administrative territorial units.

The situation of the contracts on each administrative-territorial unit can be ascertained from figure2. 


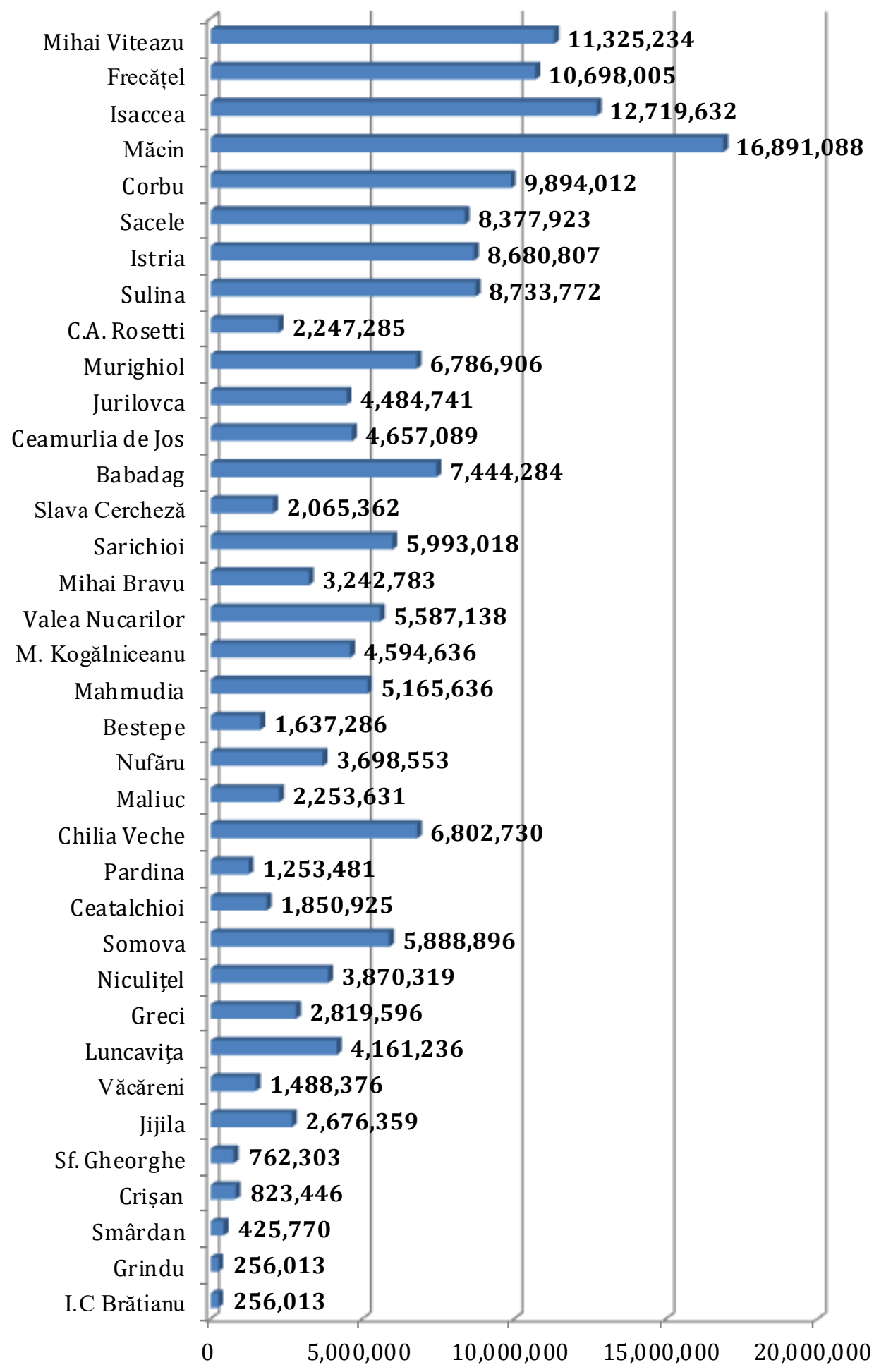

Figure 2. NRDP and ROP contracts at ITI administrative-territorial units Source: Authors, information processed based on data from AID-ITI Danube Delta (2020)

Regarding the municipality of Tulcea, the contracted amount is EUR 90.740.841, the funds coming from the seven axes of the Regional Operational Programme.

The data analysis shows that there is a low level of contracting at the ITI level, but the evaluation carried out by the Directorate-General for Internal Policies of the European Parliament in 2019 on "Integrated territorial investment as an effective instrument of the Cohesion Policy" reveals similar situations for the rest of the Member States using the ITI instrument.

Thus, according to the Commission's data, from approx. EUR 9.2 billion planned by EU for spending on ITI integrated sustainable urban development, by the end of 2018 approx. EUR 1.5 billion (16\% of the 
total) were spent, while for ITI in urban or urban-rural areas, the percentage was $13 \%$ of the planned EUR 6 billion.

The analysis carried out in the middle of the implementation period shows that it is difficult to establish the correlation between the specific characteristics of the ITI and the financial performance, but it brings some useful results:

$\checkmark$ there is no uniform model for the ITI approach at EU level and no exchange of best practices;

$\checkmark$ acceleration of implementation after a delayed start due to boosting design, selection and implementation activities (the experience of beneficiaries of European funds is important);

$\checkmark$ the benefits of integrating European funds and areas by combining funds that address complex social and economic problems;

$\checkmark$ cooperation in defining and designing the integrated development strategy;

$\checkmark$ mobilization of potential beneficiaries;

$\checkmark \quad$ strategic projects are difficult to integrate into strategies if they have not been considered since their development;

$\checkmark$ communication and visibility are not good enough etc.

\section{Conclusions}

The analysis shows the usefulness of the new instrument of Cohesion Policy, respectively the Integrated Territorial Investments, but its effectiveness has not yet been able to be concretely demonstrated.

Although the start-up of ITI implementation has been difficult due to the time needed to develop integrated territorial strategies and launch operations, the need for funding is still trying to make up for lost time. At the same time, the monitoring and evaluation structures encountered delays in preparing the procedures for selection, contracting, information and mobilization for potential beneficiaries.

However, the integration of funding sources in order to approach ITI for territorial development is particularly useful.

The perspective of the implementation of the ITI instrument must start from the elaboration of the integrated territorial strategies and strategic projects in parallel with the elaboration of the operational programmes. Also, a better mobilization and information of the beneficiaries is especially useful as the strategy has a local character and must respond to the direct local needs of the territory.

The experience gained in the programming period 2014-2020 can be shared at EU level by creating a network of ITI structures and developing good practice guides useful for Member States that want to introduce ITI or develop other ITIs at national level.

The experience of the ITI Danube Delta is particularly useful, the established territory requiring massive investments both in infrastructure and in the creation of new jobs. Identifying new possible territories to make Integrated Territorial Investments requires a realistic analysis, given that there have been several such initiatives at national level.

\section{References}

1. ADI ITI Delta Dunării, (2020), The situation of the projects in the ITI territory - April 2020, http://www.itideltadunarii.com /transparenta/situa\%C8\%9Bia-proiectelor-din-teritoriul-iti-delta-dun\%C4\%83rii, accessed September 2020

2. European Commission, (2014), Integrated Territorial Investment. Cohesion Policy 2014-2020”, https://ec.europa.eu/regional_policy /sources/docgener/informat/2014/iti_en.pdf, accessed July 2020

3. European Parliament (2015), Report on new territorial development tools in cohesion policy 2014-2020: Integrated Territorial Investment (ITI) and Community-Led Local Development (CLLD), https://www.europarl.europa.eu/doceo/document/A-8-20160032_EN.html, accessed July 2020

4. European Parliament, Directorate General for Internal Policies of the Union (2019), Integrated Territorial Investments as an effective tool of the Cohesion Policy. Budgetary Affairs, https://www.europarl.europa.eu/cmsdata/162823/25032019_CONT _Briefing_ITI_Final.pdf, accessed on July 2020

5. European Parliament, European Parliamentary Research Service, (2018)," Integrated territorial investment-Implementation and future prospects", https://www.europarl.europa.eu/RegData/etudes/BRIE/2018/614735/EPRS_BRI(2018)614735_EN.pdf, accessed on September 2020

6. Gaman, F., Luca, O., Burduja, S. I., Aldea, M., Iacoboaea, C., Petrescu, F. \& Sercăianu, M. (2015), Integrated territorial investments: challenges and opportunities - case study of Romania, https://www.researchgate.net/publication, accessed on September 2020.

7. Ionescu, R.V., Zlati, M.L., Antohi, V.A., Stanciu, S., (2018), Reduced Inequalities as Factor of Sustainable Development: The Analysis Under Econometric Models, Sustainability, 10, 3523-3545.

8. Kociuba, D. (2018), Implementation of Integrated Territorial Investments in Poland - Rationale, Results, and Recommendations, https://www.researchgate.net/publication/330282147_Implementation_of_Integrated_Territorial_Investments_in_Poland__Rationale_Results_and_Recommendations, accessed on September 2020.

9. Lădaru, G. R. and Marin, F., 2016, ITI (integrated territorial investment) - a new tool for local development financing in the programming period 2014-2020, http://www.cafee.ase.ro/wp-content/upload/2016edition/file2016(17).pdf, accessed on September 2020

10. Ministry of Public Works, Development and Administration, Territorial Cohesion Advisory Committee (2012), Integrated Territorial Investment (ITI) Consultation document, https://www.mlpda.ro/userfiles/espon/dimensiune_teritoriala/reuniune2/materiale08.pdf, accessed on July 2020.

11. Partnership agreement Romania - 2014-2020, https://ec.europa.eu/info/publications/partnership-agreement-romania-2014-20_ro, accessed on July2020 
12. Regulation (EU) No 1301/2013 of the European Parliament and of the COUNCIL of 17 December 2013 on the European Regional Development Fund and on specific provisions concerning the Investment for growth and jobs goal and repealing Regulation (EC) $N$ 1080/2006, https://eur-lex.europa.eu/legal-content/en/TXT/?uri=CELEX\%3A32013R1301, accessed on August 2020

13. Regulation (EU) No 1303/2013 of the European Parliament and of the Council of 17 December 2013 laying down common provisions on the European Regional Development Fund, the European Social Fund, the Cohesion Fund, the European Agricultural Fund for Rural Development and the European Maritime and Fisheries Fund and laying down general provisions on the European Regional Development Fund, the European Social Fund, the Cohesion Fund and the European Maritime and Fisheries Fund and repealing Council Regulation (EC) No 1083/2006, https://eur-lex.europa.eu/legal-content/EN/TXT/?uri=celex\%3A32013R1303, accessed on August 2020

14. Regulation (EU) No 1304/2013 of the European Parliament and of the Council of 17 December 2013 on the European Social Fund and repealing Council Regulation (EC) No 1081/2006, https://eur-lex.europa.eu/legal-content/EN/TXT/PDF/?uri=CELEX:32013R1304 \&from $=$ ro, accessed on August 2020

15. Stanciu, S., (2017), A Comparative Study Regarding the European Agricultural Allocation of Funds for Rural Development during 20072013 and 2014-2020, SEA - Practical Application of Science, 13, 49-55.

16. Stanciu, S., (2016), BREXIT Impact on Romania's Economy, Proceedings of the 28th International Business Information Management Association Conference: Innovation Management, Development Sustainability, and Competitive Economic Growth (Madrid, 0711.11.2017), Ed. Soliman. K.S., Vol. I, 2307-2314 